Edukids volume 15 (2) tahun 2018

EDUKIDS: Jurnal Pertumbuhan, Perkembangan, dan Pendidikan Anak Usia Dini

Jln. Dr. Setiabudhi No. 229 Kota Bandung 40154. e-mail: edukid@ upi.edu website: http://ejournal.upi.edu/index.php/edukid

\title{
KETELIBATAN ORANGTUA DALAM MENGOPTIMALKAN KEMAMPUAN BELAJAR ANAK
}

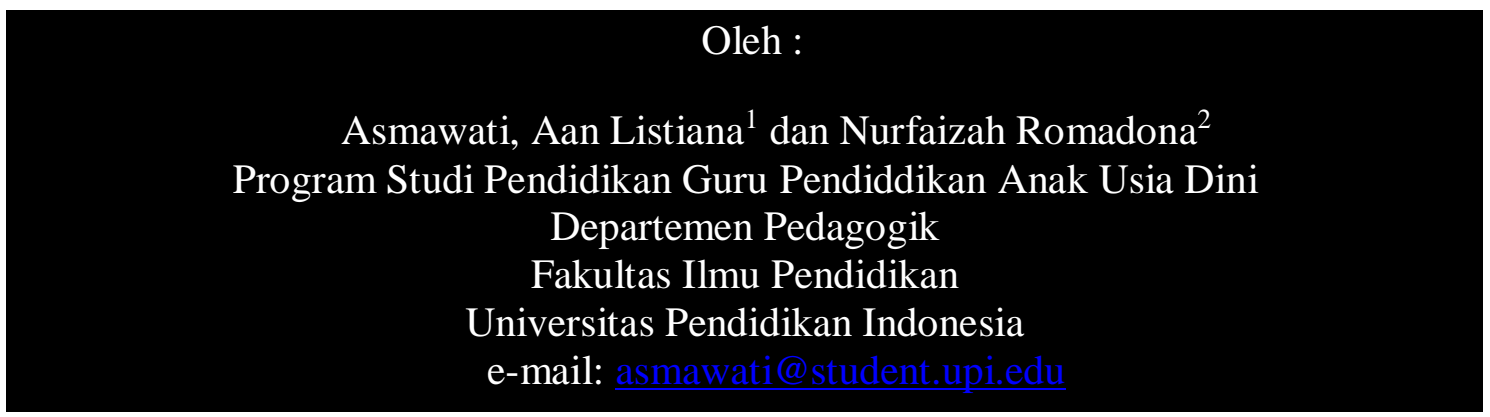

\begin{abstract}
Abstrak: Penelitian ini bertujuan untuk mengetahui gambaran keterlibatan orangtua dalam mengoptimalkan kemampuan belajar anak Se-Kecamatan Sukasari Kota Bandung Tahun Ajaran 2018/2019. Metode penelitian yang digunakan adalah survey dengan menggunakan pendekatan kuantitatif. Sampel penelitian ini adalah orang tua yang mempunyai anak berusia TK di kelompok B Se-Kecamatan Sukasri Kota Bandung dengan jumlah sampel 120 orang tua. Teknik pengambilan sampel dilakukan dengan menggunakan teknik Simple Random Sampling. Instrumen yang digunakan adalah berupa kuesioner/angket dengan hasil uji reabilitas dan validasi yang telah dilakukan dengan hasil baik tentang keterlibatan orang tua yang dikembangkan sendiri oleh peneliti. Hasil penelitian menunjukkan bahwa keterlibatan orang tua di kecamatan Sukasari Kota Bandung secara umum berada pada persentase sedang yaitu 62,50\%. Adapun bentuk keterlibatan orangtua dilingkungan rumah yaitu pada aspek memberikan pengasuhan diperoleh sebesar 47,50\%, menjalin komunikasi sebesar 63,30\%, membelajarkan anak dirumah sebesar 53\%, dan berkolaborasi dengan masyarakat sebesar 32,80\%. bentuk keterlibatan orangtua dilingkungan sekolah yaitu berperan mengambil keputusan disekolah sebesar $45 \%$, menjalin komunikasi antara orangtua dan guru disekolah sebesar $40,80 \%$, menjadi sukarelawan disekolah sebesar $60,84 \%$. Rekomendasi bagi orangtua sebaiknya dapat berperan aktif melibatkan diri dalam mengoptimalkan kemampuan belajar anak. Bagi guru PAUD diharapkan dapat berkolaborasi dengan orangtua dalam mengoptimalkan kemampuan belajar pada anak. Bagi peneliti selanjutnya yang meneliti dengan topik yang sama, dapat melakukan penelitian dengan menggunakan metode yang berbeda.
\end{abstract}

\section{Kata kunci: keterlibatan orang tua, kemampuan belajar, anak usia dini}

\begin{abstract}
This study aims to determine the description of parental involvement in optimizing children's learning abilities in Sukasari District, Bandung City 2018/2019 Academic Year. The research method used is a survey using a quantitative approach. The sample of this study is parents who have kindergarten-aged children in group $B$ of Sukasri District in Bandung City with a sample of 120 parents. The sampling technique is done using Simple Random Sampling technique. The instrument used is in the form of questionnaires / questionnaires with the results of reliability and validation tests that have been carried out with good results about parental involvement developed by researchers them selves. The results showed that the involvement of parents in the Sukasari sub-district of Bandung City was generally at a moderate percentage of $62.50 \%$.
\end{abstract}


The form of parental involvement in the home environment is in providing aspects of care obtained at $47.50 \%$, establishing communication at $63.30 \%$, teaching children at home by $53 \%$, and collaborating with the community at $32.80 \%$. the form of parental involvement in the school environment is the role of taking decisions at school by 45\%, establishing communication between parents and teachers at the school at 40.80\%, volunteering at the school at $60.84 \%$. Recommendations for parents should be able to play an active role in engaging in optimizing children's learning abilities. PAUD teachers are expected to collaborate with parents in optimizing learning abilities in children. For further researchers who are researching on the same topic, they can do research using different methods.

\section{Keywords: Parental Involvement, Optimizing Learning Abilities, Early Childhood}

\section{PENDAHULUAN}

Keterlibatan orangtua dalam pendidikan sangat diperlukan pada setiap jenjang pendidikan terlebih lagi pada lembaga PAUD (Pendidikan Anak Usia Dini). Oleh karena itu keterlibatan orangtua sangat mendukung dalam proses pembentukan karakter anak maupun dalam proses belajar anak. Pembentukan karakter itu melalui pengembangan sikap moral, agama, sosial dan emosional. Pengembangan semua nilai-nilai tersebut hanya dapat dicapai secara maksimal dengan adanya kesinambungan antara pendidikan dirumah maupun disekolah, yang tentunya tidak terlepas dari peranan orangtua. Bahwa orangtua memiliki tanggung jawab sejak akal pikiran anak belum sempurna sampai mereka mampu bertanggung jawab terhadap perbuatan mereka sendiri (Mansur, 2005, hlm. 92).

Keluarga merupakan pusat pendidikan yang pertama dan terpenting. Sejak timbulnya peradaban manusia sampai sekarang, keluarga selalu berpengaruh besar terhadap perkembangan anak manusia (Maimunah, 2012, hlm.18). Pendidikan adalah tanggung jawab bersama antara keluarga, masyarakat, dan pemerintah. Sekolah sebagai pembantu kelanjutan pendidikan dalam keluarga sebab pendidikan yang pertama dan utama diperoleh anak ialah dalam keluarga.

Keterlibatan orangtua dapat membuat anak berkembang tidak hanya pada satu aspek, tetapi pada berbagai aspek (Hornby, 2011). Keterlibatan orangtua dapat membuat prestasi akademik anak meningkat, jumlah waktu yang dihabiskan anak dengan orangtu dapat membuat prilaku sikap anak yang positif. Keterlibatan orangtua tidak hanya berdampak baik bagi anak tetapi juga orangtua dengan guru. Pada orangtua, keterlibatannya dapat meningkatkan kepuasaan dan kepercayaan diri orangtua dalam proses pengasuhan anak dan semakin tertarik pada pendidikan anak (Hornby, 2011). Bagi guru dan sekolah, keterlibatan orangtua berdampak baik pada peningkatan hubungan orangtua dengan guru, dan iklim sekolah yang lebih baik (Hornby, 2011).

Berdasarkan paparan tersebut terlihat bahwa melalui keterlibatan orangtua yang intensif terhadap tumbuh kembang anak, banyak pengaruh positif yang diperoleh anak. Disamping itu kurangnya keterlibatan orangtua dalam pendidikan anak akan mengakibatkan berbagai pengaruh buruk seperti menurunnya kemampuan prestasi belajar anak, meningkatnya prilaku antisosial, anak dapat bermalas-malasan dalam hal belajar, seenaknya sendiri berbicara hal negatif terhadap orang lain maupun hubungan yang kurang baik dengan guru dan orangtua (Maimunah, 2012, hlm.20). 
Adapun dari pembahasan tersebut bahwa keterlibatan orangtua dalam pendidikan anak maupun dalam mengoptimalkan kemampuan belajar anak sangat berpengaruh terhadap kehidupan anak selanjutnya baik pada usia dini sampai usia dewasa, keterlibatan orangtua dalam proses pendidikan anak tidak hanya saja berpengaruh di usia dini akan tetapi akan berpengaruh kemasa yang panjang yaitu usia remaja sampai usia dewasa adapun pengaruh ialah berdasarkan penelitian di lakukan di Amerika Serikat terhadap 15.000 remaja menunjukkan bahwa jika peranan keluarga berkurang/terabaikan atau tidak dilakukan, maka dampak yang paling signifikan yang terjadi yaitu 1.) Peningkatan jumlah anak putri usia belasan tahun hamil tanpa menikah, 2) Peningkatan kriminalitas yang dilakukan oleh anak-anak, 3) Patologi psikososial. Alasan pentingnya keterlibatan orangtua dalam mengoptimalkan kemampuan belajar anak ialah orangtua merupakan guru pertama dan yang terpenting bagi anak.

Berbagai hasil penelitian menunjukkan bahwa bila orangtua berperan dalam pendidikan, anak akan menunjukkan peningkatan prestasi belajar, diikuti dengan perbaikan sikap, stabilitas sosioemosional, kedesiplinan, serta aspirasi anak untuk belajar sampai perguruan tinggi, bahkan setelah bekerja dan berumah tangga. Maimunah (2012: 20) mengungkapkan bahwa, anak termasuk individu unik yang mempunyai eksistensi dan memiliki perkembangan jiwa sendiri, serta mempunyai hak untuk tumbuh dan berkembang secara optimal sesuai dengan perkembangannya masingmasing yang khas. Masa kehidupan anak sebagian besar berada dilingkup keluarga. Karena itu keluarga adalah salah satu yang paling menentukan terhadap masa depan anak. Begitu pula corak anak dilihat dari perkembangan sosial, psikis, fisik, dan sikap religius juga ditentukan oleh keluarga (Hidayat, 2009: 6).

Berdasarkan latar belakang yang telah diuraikan, maka penelitian memfokuskan kajian penelitian tentang keterlibatan orangtua dalam mengoptimalkan kemampuan belajar anak. Adapun rumusan masalah dalam penelitian ini dijabarkan dalam pertanyaan sebagai berikut:

1. Bagaimana profil keterlibatan orangtua dalam mengoptimalkan kemampuan belajar anak di Taman Kanak-Kanak SeKecamatan Sukasari Kota Bandung Tahun Ajaran 2018/2019?

2. Bagaimana keterlibatan orangtua dalam mengoptimalkan kemampuan belajar anak di Taman Kanak-Kanak SeKecamatan Sukasari Kota Bandung Tahun Ajaran 2018/2019 Berdasarkan aspek memberikan pengasuhan, menjalin komunikasi, membelajarkan anak dirumah, mengambil keputusan disekolah, menjalin komunikasi antara orangtua dan guru disekolah, menjadi sukarelawan disekolah, berkolaborasi dengan masyarakat?

Sesuai dengan rumusan masalah di atas, maka tujuan penelitian ini adalah sebagai berikut:

1) Untuk mengetahui profil keterlibatan orangtua dalam mengoptimalkan kemampuan belajar anak di Taman KanakKanak Se-Kecamatan Sukasari Kota Bandung.

2) Untuk mengetahui Bagaimana keterlibatan orangtua dalam mengoptimalkan kemampuan belajar anak berdasarkan aspek memberikan pengasuhan, menjalin komunikasi, 
membelajarkan anak dirumah, berperan mengambil keputusan disekolah, menjalin komunikasi antara orangtua dan guru disekolah, menjadi sukarelawan disekolah dan berkolaborasi dengan masyarakat.

\section{METODE PENELITIAN}

Desain penelitian ini menggunakan metode penelitian survei dengan pendekatan kuantitatif. Effendi (2014, hlm. 3) mengungkapkan bahwa metode survei adalah metode yang mengambil sampel dari satu populasi dengan menggunakan kuesioner sebagai alat pengumpul data yang pokok.

Populasi dalam penelitian ini adalah seluruh orangtua yang menyekolahkan anak di kelompok B Taman Kanak-kanak di Kec. Sukasari Kota Bandung Tahun Ajaran 2018/2019, dengan jumlah keseluruhan anak TK (Taman Kanak-Kanak) sebanyak 1049 dari 17 Taman Kanak-Kanak di Kec. Sukasari Kota Bandung. Adapun karaktrestik spesifik pemilihan partisipan adalah Orangtua yang mempunyai anak berusia TK dikelompok B Se-Kecamatan Suksasari Kota Bandung.

Instrumen yang digunakan dalam penelitian ini adalah berupa kuesioner (angket) dengan jenis angket langsung tertutup (angket terstruktur). Instrumen penelitian dalam penelitian ini, dibuat oleh peneliti sendiri yang mengacu pada teori Morrison (2012: 378).

\section{A. HASIL PENELITIAN DAN PEMBAHASAN}

1. Keterlibatan Orangtua Dalam Mengoptimalkan Kemampuan Belajar Anak di Taman Kanak-Kanak SeKecamatan Sukasari Kota Bandung Tahun Ajaran 2018/2019 Secara Umum
Berdasarkan hasil penelitian yang dilakukan pada 120 responden orangtua ditemukan sebanyak 38 orangtua berada pada kategori tinggi sebanyak $31,7 \%, 75$ orangtua berada pada kategori sedang sebanyak 62,5\%, enam orangtua berada pada kategori rendah sebanyak $5 \%$, dan satu orangtua berada pada kategori sangat rendah sebanyak $0,80 \%$. Adapun secara umum dapat dipaparkan bahwa keterlibatan orangtua dalam mengoptimalkan kemampuan belajar anak berada pada kategori sedang dengan jumlah responden 75 orangtua sebesar $62,5 \%$.

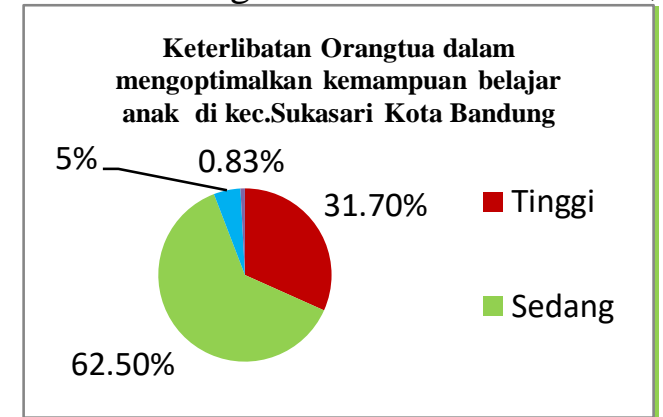

2. Keterlibatan Orangtua Dalam Mengoptimalkan Kemampuan Belajar Anak di Taman Kanak-Kanak SeKecamatan Sukasari Kota Bandung Tahun Ajaran 2018/2019 Berdasarkan Aspek-Aspek.

\section{a. Aspek Memberikan Pengasuhan}

Berdasarkan penelitian ditemukan bahwa sebanyak 57 responden orangtau berada pada kategori tinggi sebesar $47,5 \%, 55$ orangtua berada pada kategori sedang sebesar $45,8 \%$, delapan orangtua pada kategori rendah sebanyak 6,7\%, dan tidak ada responden orangtua yang termasuk dalam kategori sangat rendah.

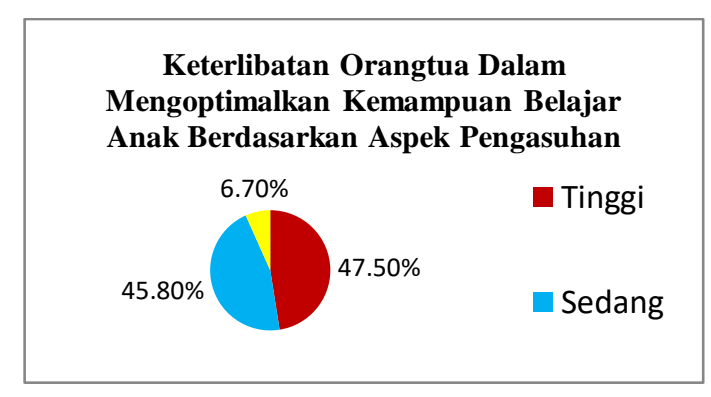




\section{b. Aspek Menjalin Komunikasi}

Berdasarkan hasil penelitian ditemukan sebanyak 76 responden orangtua berada pada kategori tinggi sebanyak 63,3\%, 36 orangtua berada pada kategori sedang sebanyak 30\%, tujuh responden orangtua berada pada kategori rendah sebanyak 5,9\% dan satu responden orangtua berada pada kategori sangat rendah sebesar $0,80 \%$.

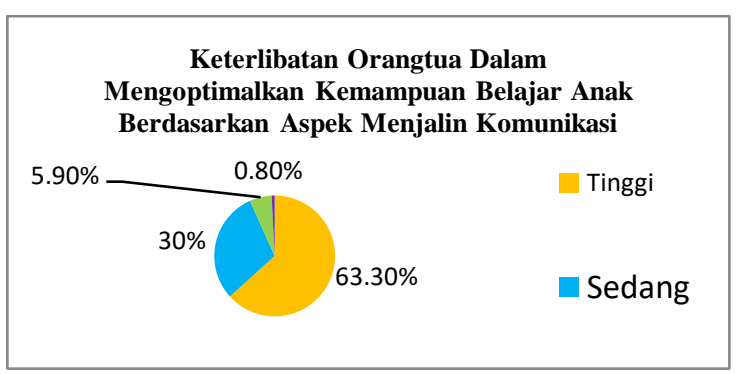

\section{c. Aspek Membelajarkan dirumah}

Berdasarkan penelitian ditemukan sebanyak 44 orangtua berada pada kategori tinggi sebanyak 36,6\%, 63 orangtua berada pada kategori sedang sebanyak 52,5\%, 13 orangtua berada pada kategori rendah sebanyak 10,9\% dan tidak ada responden orangtua yang termasuk dalam kategori sangat rendah.

Keterlibatan Orangtua dalam
Mengoptimalkan Kemampuan Belajar
Anak Berdasarkan Aspek
Membelajarkan Anak diRumah

\section{d. Aspek Berperan Mengambil Keputusan Di Sekolah}

Berdasarkan penelitian terdapat 54 orangtua berada pada kategori tinggi sebanyak $45 \%, 46$ orangtua berada pada kategori sedang sebanyak 38,4\%, 20 orangtua berada pada kategori rendah sebanyak $16,6 \%$ dan tidak ada responden orangtua yang termasuk dalam kategori sangat rendah.

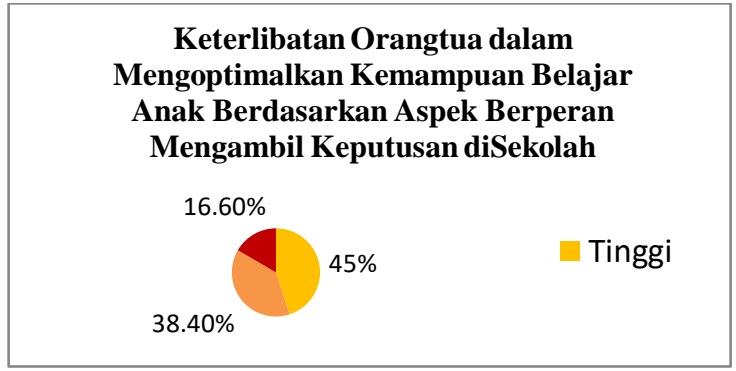

\section{e. Aspek Menjalin Komunikasi Antara Orangtua Dan Guru Disekolah}

Berdasarkan penelitian terdapat 49 orangtua berada pada kategori tinggi sebanyak 40,8\%, 41 orangtua berada pada kategori sedang sebanyak 34,2\%, 30 orangtua berada pada kaegori rendah sebanyak $25 \%$, dan tidak ada responden orangtua yang termasuk dalam kategori sangat rendah.

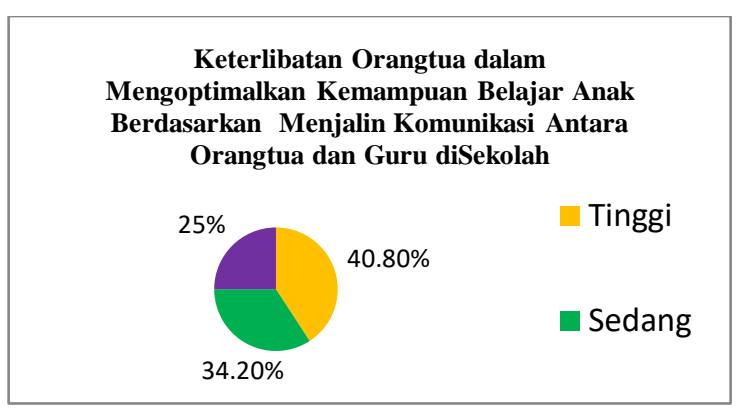

\section{f. Aspek Menjadi Sukarelawan diSekolah}

Berdasarkan penelitian terdapat tujuh responden orangtua berada pada kategori tinggi sebesar 5,83\%, 73 orangtua berada pada kategori sedang sebanyak $60,84 \%$, 37 orangtua berada pada kategori rendah sebanyak $30,83 \%$, dan tiga responden orangtua berada pada kategori sangat rendah sebanyak $2,5 \%$.

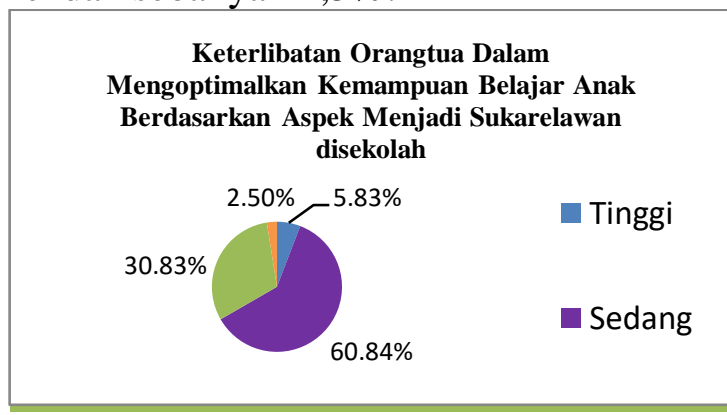

g. Aspek Berkolabrosi
Masyarakat


Berdasarkan penelitian terdapat 34 responden orangtua berada pada kategori tinggi sebanyak 29,2\%, 39 orangtua berada pada kategori sedang sebanyak 32,5\%, 43 orangtua berada pada kategori rendah sebanyak 32,8\% dan tiga responden orangtua berada pada kategori sangat rendah sebanyak 2,5\%

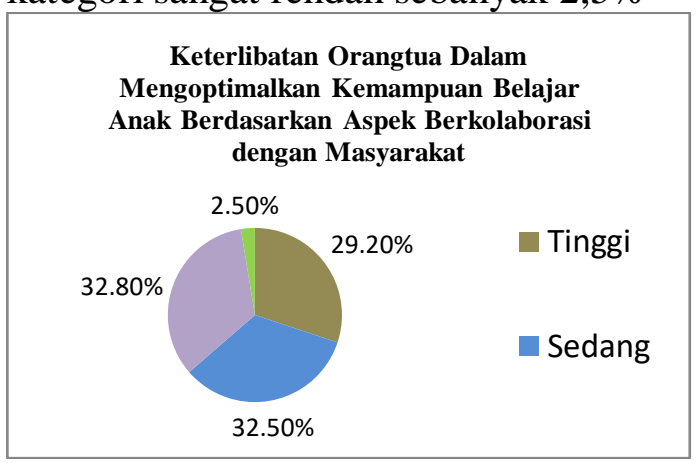

\section{PEMBAHASAN}

\section{Profil Keterlibatan Orangtua Dalam Mengoptimalkan Kemampuan Belajar Anak Di Taman Kanak-Kanak Se- Kecamatan Sukasari Kota Bandung Tahun Ajaran 2018/2019}

Dari hasil penelitian ini bahwa mayoritas orangtua di Taman KanakKanak Se-Kecamatan Sukasari Kota Bandung memiliki keterlibatan yang sedang terhadap keterlibatan orangtua dalam mengoptimalkan kemampuan belajar anak yaitu 75 orangtua sebesar $62,5 \%$, nilai skor tersebut dapat dikategorikan dengan interpretasi skor sangat kuat, namun apabila dilihat dari persentase keterlibatan orangtua dalam mengoptimalkan kemampuan belajar anak yaitu 38 orangtua berada pada kategori tinggi sebesar $31,7 \%$ dengan interpretasi skor sangat lemah. Skor tersebut sangat tidak terlalu memperhatinkan karena dilihat dari hasil penelitian hanya sebagian besar orangtua sudah terlibat dalam mengoptimalkan kemampuan belajar anak dan sebagian kecilnya orangtua masih belum terlibat dalam mengoptimalkan kemampuan belajar anak di Taman Kanak-Kanak
(TK) di Kecamatan Sukasari Kota Bandung.

Oleh karena itu secara teori terdapat bahwa dari hasil penelitian faktor yang mempengaruhi orangtua sebagian kecil tidak terlibat dalam mengoptimalkan kemampuan belajar anak ialah keyakinan orangtua tentang pentingnya keterlibatan mereka dalam pendidikan anak jadi salah satu pendukung keterlibatan orangtua dalam pendidikan anak adalah keyakinan orangtua akan pentingnya orangtua dalam pendidikan akan tetapi hal tersebut menjadi penghambat orangtua dalam proses mengoptimalkan belajar anak karena orangtua tidak percaya diri dalam hal pendidikan anak, hal lainnya yang menghambat orangtua ialah faktor persepsi orangtua terhadap undangan keterlibatan disekolah, persepsi tersebut ialah orangtua akan sangat tergantung pada sikap yang ditunjukan oleh guru ke orangtua akan terlihat lebih efektif apabila kehadiran mereka disekolah dihargai oleh guru atau pihak sekolah lainnya.

Berdasarkan hal tersebut, upaya yang harus dilakukan dalam mengoptimalkan kemampuan belajar anak bagi orangtua agar partisipasi dalam mengoptimalkan kemampuan belajar anak meningkat ialah menurut teori Epstein, dkk (2012) adanya kepercayaan yang lebih dalam mengasuh anak dalam hal belajar, pengetahuan tentang perkembangan anak, komunikasi dan intraksi yang mudah dengan guru dan sekolah, pemahaman terhadap tugas guru yaitu bertukar informasi tentang perkembangan anak disekolah, sering melakukan diskusi dengan anak tentang setiap hal yang mencakup pendidikan disekolah, maupun pemahaman tentang kurikulum sekolah dan bagaimana membantu anak dalam proses perkembangan belajar yang dipelajari anak dan dapat membuat anak tertarik untuk belajar. 
2.Keterlibatan Orangtua Dalam Mengoptimalkan Kemampuan Belajar Anak di Taman Kanak-Kanak SeKecamatan Sukasari Kota Bandung Tahun Ajaran 2018/2019 Berdasarkan Aspek-Aspek.

Dari pemaparan diatas dapat disimpulkan bahwa keterlibatan orangtua dalam mengoptimalkan kemampuan belajar anak ditaman kanak-kanak se kecamatan sukasari kota Bandung tahun ajaran 2018/2019 dari hasil penelitian keseluruhan yang dilakukan terhadap 120 responden orangtua ditemukan sebanyak 75 responden orangtua berada pada kategori sedang dapat dilihat bahwa keterlibatan orangtua dalam mengoptimalkan kemampuan belajar anak secara keseluruhan belum berada pada kategori tinggi adapun faktor yang mempengaruhi kurangnya partisipasi orangtua dalam proses mengoptimalkan belajar anak dapat dilihat dari faktor lingkungan rumah dari aspek pengasuhan, menjalin komunikasi, membelajarkan anak dirumah, berkolaborasi dengan masyarakat dapat dilihat bahwa keterlibatan orangtua secara umum sekolah dan orangtua maupun lingkungan sekitar masih berada pada kategori rendah dalam memanfaatkan sumber-sumber masyarakat untuk membantu proses pembelajaran anak yaitu seperti kegiatan parenting yang dilakukan dilingkungan sekitar dan pada faktor lingkungan sekolah pada aspek berperan mengambil keputusan disekolah, komunikasi antara orangtua dan guru disekolah, dan menjadi sukarelawan disekolah berada pada kategori sedang dimana orangtua dapat memahami bahwa keterlibatan mereka disekolah sangat dibutuhkan dimana orangtua dapat mendampingi anak ketika berada diluar lingkungan sekolah seperti rekreasi dan lain sebagainya.

Dari keseluruhan aspek bahwa faktor utama yang mempengaruhi orangtua kurang telibat dalam mengoptimalkan kemampuan belajar anak ialah kurangnya kepercayaan diri yaitu latar belakang pendidikan orangtua yang rendah, pengalaman masa lalu dalam pendidikan, rasa rendah diri orangtua dalam permasalahan pribadi lainnya seperti jarak rumah dan sekolah jauh yang membuat orangtua enggan hadir dalam kegiatan yang diadakan pihak sekolah, faktor lainnya yaitu kurangnya persepsi/ respon guru terhadap orangtua yang hadir dilingkungan sekolah sehingga orangtua menarik diri dari lingkungan sekolah dan apabila orangtua terlibat efektif apabila kehadiran mereka disekolah dihargai oleh guru dan pihak sekolah lainnya. Selanjutnya faktor yang mempengaruhi ialah faktor anak dimana ketika usia anak bertambah maka keterlibatan orangtua akan berkurang dalam mengoptimalkan kemampuan belajar anak dan dimana ketika anak sudah mampu mengikuti kegiatan belajar dengan baik akan mengurangi pelibatan orangtua sehingga akan berkurangnya latihan setiap aspek-aspek perkembangan anak itu sendiri.

\section{SIMPULAN, IMPLIKASI DAN REKOMENDASI}

\section{A. SIMPULAN}

Berdasarkan hasil penelitian dan pembahasan diperoleh beberapa simpulan sebagai berikut :

1. Profil keterlibatan orangtua dalam mengoptimalkan kemampuan belajar anak di Taman Kanak-Kanak SeKecamatan Sukasari Kota Bandung Tahun Ajaran 2018/2019 maka dari data penelitian terhadap responden orangtua 120 sampel menghasilkan kesimpulan bahwa secara umum keterlibatan orangtua dalam mengoptimalkan kemampuan belajar anak terdapat 75 orangtua berada pada kategori sedang sebesar $62,5 \%$.

2. Pada aspek memberikan pengasuhan orangtua terlibat dalam 
menyediakan media pembelajaran untuk mendukung perkembangan belajar anak ditemukan bahwa 57 orangtua berada pada kategori tinggi sebesar $47,5 \%$, pada aspek menjalin komunikasi orangtua terlibat aktip dalam mengajak anak untuk berbicara dalam hal belajar terdapat responden orangtua berjumlah 76 berkriteria tinggi sebesar 63,3\%, pada aspek membelajarkan anak dirumah orangtua terlibat dalam membantu stimulasi perkembangan belajar anak dirumah melalui permainan edukatif terdapat 63 orangtua berada pada kategori sedang sebesar 52,5\%, aspek berperan mengambil keputusan disekolah orangtua terlibat aktip dalam menghadiri rapat yang diadakan pihak sekolah terdapat 54 orangtua berada pada kategori tinggi sebesar $45 \%$, aspek menjalin komunikasi antara orangtua dan guru disekolah orangtua terlibat dalam menanyakan kemajuan anak dalam hal belajar kepada guru kelas dan terdapat 49 orangtua berada pada kategori tinggi sebesar 40,8\%, pada aspek menjadi sukarelawan disekolah orangtua terlibat dalam mendampingi anak ketika diadakan kegiatan yang diluar sekolah terdapat 73 orangtua berada pada kategori sedang sebesar $60,84 \%$, dan pada aspek berkolaborasi dengan masyarakat orangtua dan sekolah terlibat dalam memanfaatkan sumber-sumber masyarakat untuk membantu pembelajaran anak dilingkungan terdapat 43 orangtua berada pada kategori rendah sebesar $43 \%$.

\section{B. IMPLIKASI}

Adapun implikasi dari penelitian ini diantaranya yaitu sebagai berikut:

Keterlibatan orangtua dalam proses perkembangan belajar anak sangatlah penting, maka dari itu apabila orangtua tidak terlibat aktif dalam proses mengoptimalkan kemampuan belajar anak, akan sangat mempengaruhi baik dalam segi positif maupun negatif terhadap perkembangan anak pada setiap fase-fase perkembangannya. Dengan demikian orangtua dan guru hendaknya memahami bahwa keterlibatan orangtua akan sangat berpengaruh terhadap pendidikannya bahwa keterlibatan orangtua merupakan hal yang sangat penting untuk mendukung perkembangannya dan proses belajar anak dan jika sebaliknya orangtua dan guru tidak memahami proses perkembangan anak akan berpengaruh ke hal yang negatif. Dari hal tersebut orangtua dapat menyediakan media pembelajaran yang menarik untuk anak dan mendukung setiap perkembangan khususnya belajar anak, dan orangtua mampu membantu stimulasi perkembangan belajar anak dirumah melalui permainan edukatif maupun mengetes kemampuan belajar anak dirumah melalui media pembelajaran edukatif dan yang menyenangkan buat anak.

\section{REKOMENDASI}

Berdasarkan hasil kesimpulan di atas, penulis memberikan saran demi perbaikan dan juga untuk memberikan gambaran kepada semua pihak terkait keterlibatan orangtua dalam mengoptimalkan kemampuan belajar anak di Taman Kanak-Kanak SeKecamatan Sukasari Kota Bandung Tahun Ajaran 2018/2019. Adapun rekomendasi tersebut yaitu:

\section{Bagi Orangtua}

Orangtua diharapkan lebih berperan aktip melibatkan diri dalam mengoptimalkan kemampuan belajar anak seperti memberikan pengasuhan yang baik untuk anak seperti menyediakan media pembelajaran untuk mendukung perkembangan belajar anak sebagai contoh 
mengulang kembali kegiatan yang diadakan sekolah seperti disekolah melakukan kegiatan melatih kemampuan keingintahuan anak melalu eksperimen sain, bertanya jawab apa yang dilakukan anak disekolah dapat melatih aspek kognitif anak, bahasa dan sebagainya, adapun melalui permainan edukatif mampu meningkatkan prestasi belajar anak seperti permainan puzzle jam dapat melatih kemampuan kognitif, bahasa, mengenalkan warna dan yang menarik bagi anak yaitu dapat menstimulasi setiap perkembangan khusunya pengetahuan belajar anak.

\section{Bagi Guru}

Guru diharapkan dapat lebih aktif bekerjasama dengan orangtua, sehingga guru dapat memberikan informasi yang bermanfaat bagi orangtua baik dalam segi pengasuhan, belajar dirumah, komunikasi antara orangtua dan guru, memberikan pemahaman tentang belajar untuk anak usia dini ketika melakukan kegiatan rapat disekolah mengenai penjelasan belajar anak usia dini. karena masih banyak orangtua yang belum dapat membedakan belajar anak usia dini dengan belajar anak sekolah dasar, sehingga orangtua mengaplikasikannya dengan hal yang sama, padahal belajar anak usia dini melalui media pembelajaran yang menarik dan dapat menyenangkan bagi anak usia dini.

\section{Bagi Peneliti Selanjutnya}

Hasil penelitian diharapkan menjadi acuan untuk mengembangkan penelitian selanjutnya tentang keterlibatan orangtua dalam mengoptimalkan kemampuan belajar anak.

\section{DAFTAR PUSTAKA}

Effendi, dkk. (2014). Metode Penelitian Survei. Jakarta: LP3ES.

Epstein, R. dkk. (2004). Panduan Lengkap Motivasi. Yogyakarta: Pustaka Kendi.

Hidayat. (2009). Metode Penelitian Kebidanan Tekhnik Analisis Data. Jakarta: Salemba Medika.

Hornby, Garry. (2011). Parental Involvement in Childhood Education: Building Effective School-Family Partnerships. New York: Springer.

Maimunah, H. (2012). Pendidikan Anak Usia Dini. Yogyakarta: Diva Press.

Mansur. (2005). Pendidikan Anak Usia Dini Dalam Islam. Yogyakarta: Pustaka Pelajar.

Morrison, S. \& Zhang. (2012). Accessible family involvement in early childhood education program. Dimensions of early Childhood Education, 39 (3), hlm. 21-25. 